\title{
Kultūros politikos iggyvendinimas: teorinis konceptualizavimas ir modeliai
}

\author{
Audronė Pauliukevičiūtė \\ Kauno technologijos universitetas \\ Ekonomikos ir verslo fakultetas \\ Laisvès al. 55, LT-44309 Kaunas, Lietuva \\ Alvydas Raipa \\ Mykolo Romerio universitetas \\ Politikos ir vadybos fakultetas \\ Valakupiu g. 5, LT-10101 Vilnius, Lietuva \\ doi:10.13165/VPA-14-13-2-05
}

\begin{abstract}
Anotacija. Besikeičiantis, sparčiai globalëjantis technologizuotas pasaulis, nuolatine progresine kaita ir kultūru tranformacijos lemia pokyčius ir valstybiu valdymo sistemose, atskirose viešosios politikos ir vadybos srityse. Kultūros politikos igyvendinimas yra veikiamas politiniu/ideologiniu, ekonominiųorganizaciniu, kultūrinių/ technologiniu iššükiu ir nepaisant gausiu kultūros politikos klausimus nagrinëjančiu tyrimu, yra pasigendama platesnio požiürio ị kultūros politikos igyvendinimo konceptualizavima, su procesu siejamas problemas. Todèl šio straipsnio tikslas yra atskleisti kultūros politikos igyvendinimo ir jo modeliu teorini konceptualizavima. Darbo objektas - kultūros politikos igyvendinimo koncepcijos ir teoriniai modeliai. Darbo tikslui pasiekti formuluojami du uždaviniai: konceptualizuoti kultūros politikos igyvendinima, apžvelgiant koncepto interpretacijas ir apibüdinant kultūros politikos igyvendinima kaip viešosios politikos igyvendinimo sritị; apibüdinti teorinius kultüros politikos igyvendinimo valstybiniu lygmeniu modelius. Straipsnio autoriai pateikia platu kultūros politikos igyvendinimo sampratu spektra, apibüdina pagrindinius modelius, atskleidžia ir vizualizuoja kultūros politikos igyvendinimo procesa (nepriklausomai nuo pasirinkto modelio) viešosios politikos igyvendinimo proceso bendruju kintamuju kontekste.
\end{abstract}

Raktažodžiai: kultūros politika, kultūros politikos iggyvendinimas, viešoji politika, kultūros politikos igyvendinimo modeliai. 
Keywords: cultural policy, cultural policy implementation, public policy, cultural policy implementation models.

\section{İvadas}

Kultūros politikos ịgyvendinimo tema, nepaisant sąsajų su skirtingomis mokslo sritimis (kultūros studijomis, kultūrine antropologija, kultūrine ekonomika, politine sociologija, meno organizacijų vadyba ir kt.), reikalauja išskirtinio dèmesio ir platesnès analizès vadybos, viešosios politikos, administravimo studijų lygmeniu dèl paties reiškinio ir proceso (kurio negali aprèpti tik vienos srities mokslo tyrimų išvados) kontekstualumo bei su juo susijusių semantinių/lingvistinių, politinių/metodologinių ir vadybinių/administracinių klausimų. M. Pyykkönen, N. Simanainen ir S. Sokka pabrėžia, kad ,yra svarbu skatinti mokslines diskusijas, susijusias su kultūros pamatinėmis idejomis, politika ir administravimu, atveriant plataus profilio kultūros teorinių ir praktinių tyrimų lauką“" [26, p. 27].

Kultūros politikos ịgyvendinimas yra nagrinèjamas daugelio autorių: kultūros politikos teoriniame kontekste Raymond Williams nagrinejo esmines sampratas [33], Pirkkoliisa Ahponen ir Anita Kangas - kultūros politikos turinio klausimus, konceptualizavimą, regioninę ir vietos kultūros politiką, kultūros politikos istoriją [1], Ritva Mitchell - Europos Sąjungos kultūros politiką, nacionalinès kultūros politikos klausimus [22], Eleonora Belfiore ir Oliver Bennet - menų politiką, socialinius kultūros politikos aspektus [4; 5], Clive Gray, Jenny Johannisson - kultūros politikos teorinius konstruktus, kultūros politiką regionuose $[15 ; 16 ; 17]$, Esa Pirnes - kultūros politikos esminius modelius [25], Miikka Pyykkönen, Niina Simanainen ir Sakarias Sokka - kultūros politikos tarpdiscipliniškumą, istorinius aspektus, subkultūras, pilietinès visuomenès įtaką kultūros raidai [26], Lidia Varbanova - strateginius kultūros politikos igyvendinimo aspektus, strategini planavimą, kultūros organizacijų programų ir projektų vadybą [36]. Kultūros politikos igyvendinimo konceptualizavimas ir modeliai nagrinèti daugelio autorių $[1 ; 9 ; 10$; $15 ; 16 ; 22 ; 25 ; 26 ; 38 ; 39]$.

Kultūros studijų, kritinès teorijos ir kultūros sektoriaus valdymo sąsajas savo mokslo darbuose atskleide Kenneth Thompson, John Eastin Van Maanen, Edgar Henry Schein [32; 34]. Nacionalinius kultūrinius elgsenos tyrimus, socializacijos klausimus organizacijų kultūros teorijos kontekste atliko Geert Hofstede [14]. Ivairūs su kultūros politika siejami teoriniai tyrimai Lietuvoje daugiausia akcentuoja kultūros politikos turinị, kultūros kaip socialinès srities/sferos problemas, meno organizacijų vadybos, verslo kultūros ir Europos Sąungos įtakos tarptautiniam kultūros sričių vystymui klausimus [2; 9; 10; 19; 21; 38; 39].

Atsižvelgdami ì kultūros kaip plataus tyrimų objekto ir ganėtinai abstraktaus termino [26, p. 11] kontekstualios analizès poreikị ir suvokdami, jog remiantis W. N. Dunn ,bet kurios politikos analizès tikslas yra tobulinti politikos formavimą“ $[12$, p. 68], šiame straipsnyje autoriai pagrindinę darbo problemą formuluoja klau- 
simu: kaip pasitelkiant kultūros politikos ir viešosios politikos ịgyvendinimo požiūrius konceptualizuoti kultūros politikos igyvendinimą ir jo teorinius modelius?

Straipsnio tikslas - atskleisti kultūros politikos igyvendinimo ir jo modelių teorinị konceptualizavimą. Darbo objektas - kultūros politikos ịgyvendinimo koncepcijos ir teoriniai modeliai. Darbo tikslui pasiekti formuluojami šie uždaviniai: (1) konceptualizuoti kultūros politikos iggyvendinimą, apžvelgiant koncepto interpretacijas ir apibūdinant kultūros politikos ịgyvendinimą kaip viešosios politikos ịgyendinimo sritị; (2) apibūdinti teorinius kultūros politikos igyvendinimo valstybiniu lygmeniu modelius (vizualizuojant ir kultūros politikos ịgyvendinimo proceso (nepriklausomai nuo pasirinkto modelio) sąsajas su viešosios politikos ígyvendinimo proceso bendrųjų kintamųjų sąveika). Darbe taikyti šie metodai: lyginamoji ir sisteminè mokslinès literatūros analizè, kritinè analizè, sistematizavimas.

\section{Kultūros politikos įgyvendinimo teorinis konceptualizavimas}

\section{Kultūros politikos igyvendinimo koncepto interpretacijos}

Teoriniam kultūros politikos ịgyvendinimo valstybiniu lygmeniu konceptualizavimui lemiamos reikšmès turi kultūros sampratos tyrimai, viešosios politikos ir kultūros politikos sąsajos, politikos ịgyvendinimo kaip administracinių ir vadybinių iššūkių kupino proceso apibrèžtis. Kultūra - tai apibūdinanti visuomenès raidos lygị socialinè sistema, garantuojanti materialinių ir dvasinių vertybių kūrimą, panaudojimą ir perteikimą [35]. P. Ahponen ir A. Kangas pabrěžia, kad „kultūros politika yra neabejotinai susijusi su visomis pagrindinèmis visuomenès veiklos sritimis" [1, p. 246]. Kaip visuomeneje yra keliama politinè problema ir kokiais būdais igyvendinama atitinkama politika, visada priklauso ir nuo dominuojančio ar tiesiog pasirenkamo teorinio požiūrio. XIX a. pradedant kultūrą sieti su kolektyvinio vystymosi procesais, kultūra pradèta plačiai tapatinti su meno rūšimis ir sritimis, ji buvo apibrèžiama iš nacionalinių valstybių perspektyvos lauko ir tai dèsninga, kadangi tuo laikotarpiu dauguma politikos studijų objektų taip pat neperžengdavo nacionalinių ribų, o tarptautiniai veiksniai nebuvo nuosekliai stebimi, neretai net ir neatpažistami. Regioninių ar vietos politikos institucijų veikla dažniausiai buvo siejama su pavaldumo centralizuotai sistemai išraiškomis tiek politikoje, tiek ir jos studijose [26, p. 11]. XIX a. pabaigoje buvo susieti „kultūros“ ir „visuomenès vystymosi" požiūriai, išskiriant kultūros poveikị visuomenių raidai, gausèjo mokslinių darbų, pabrèžiančių visuomenès institucijų (viešųjų politinių institucijų iš XXI a. perspektyvos) įtaką formuojant kultūrai palankią aplinką valstybèse, taip pat kultūros pagrindu skatinamas socialinių pokyčių aplinkybes. Vykstant ekonominėms ir politinèms transformacijoms, XIX a. pabaigos - XX a. vidurio laikotarpis atnešè svarių postūmių visuomenių socialinių, politinių ir kultūrinių kontekstų tyrimuose. Kultūros politikos iggyvendinimo mokslinėms ištakoms reikšmingos įtakos turèjo ir dauguma Europos XX a. vidurio filosofinès ir sociologinès minties atstovų [32, p. 599]. Moksliniuose diskursuose pradeda dominuoti įvairiai analizuojamos, adap- 
tuojamos ar kritikuojamos R. Williams išskirtos trys koncepto „kultūra“ variacijos: (1) „kultūra“ kaip bendras estetinis, dvasinis ir intelektinis vystymosi procesas;

(2) „kultūra“ kaip ypatingas gyvenimo būdas, tam tikros elgsenos prototipas, sietinas su tautos, grupės žmonių ar istorinio laikotarpio diktuojamomis tradicijomis; (3) „kultūra“ kaip intelektinès ir meninès veiklos darbai ir praktikos [33, p. 90]. Klasikinėms kultūros politikos ịgyvendinimo sampratoms priskiriami ir XX a. pradèję ryškèti organizacinès kultūros teoretikų požiūriai: „kultūra - tai bendros visuomenès ar grupès narių vertybès, lūkesčiai ir ịsitikinimai““ [34]; „kultūra - tai kolektyvinis proto programavimas, atskiriantis vienos grupès narius nuo kitos" [14]. Svarbu akcentuoti, jog kultūra kaip menas yra tik dalis plataus termino. Todèl šiame straipsnyje yra remiamasi kontekstualia R. Williams interpretacija (aprépiančia tris prieš tai minètas koncepto suvokimo variacijas) - kultūros politikos igyvendinimą suprantant kaip „visuomenei svarbią suvoktą ir turinčią reikšmę sistemą“ [33, p. 207-208; 26, p. 27]. Autorių pasirinkimą pagrindžia ir siekis teoriškai konceptualizuoti kultūros politiką ne kaip politinių studijų, bet kaip vadybos ir viešojo valdymo mokslų objektą. Todèl kreipiamas papildomas dėmesys ir ị kultūros politikos igyvendinimo koncepto vadybines dimensijas (tokias, kaip kultūros politikos vartotojai, kūrejjai ir kiti suinteresuotieji, kultūros politikos kontekstą, kultūros politikos priemones ir formas, kultūros politikos tipus, kultūros politikos strategiškumą ir rezultatus bei kt.). Kaip buvo pabrěžęs P. Duelund: „kultūros politika taip pat gali būti identifikuojama ir kaip specifinis ị visuomenès poreikių tenkinimą nukreiptas kultūros sektorius“" [11, p. 13]. Tokios apibrèžties privalumas yra svarbus, nes sujungia „kultūrą“" ir politiką" tuo aspektu, kuris yra pakankamai platus, kad būtų nagrinejjamas valstybių viešojo valdymo srityje ir pakankamai siauras, kad būtų išvengta svarstymų, susijusių su konkrečiomis politikos turinio interpretacijomis. Kultūros politikos įgyvendinimo koncepto interpretacijos nuo vienų pirmųjų, sietinų dar su 1963 m. G. Almond ir S. Verba suformuluotomis politinès kultūros idejjomis, iki pat XXI a. naujausių ižvalgų - kito, tačiau visuomet buvo jaučiamas teorinis siekis sistemiškai konceptualizuoti politikos turinị, kryptis ir rezultatus, atsižvelgiant ị kultūrinès elgsenos ir meno sričių ịvairovę. Administracinès kultūros konceptas taip pat tapo viena pirmujjų kultūros politikos iggyvendinimo terminijos sampratų [20; 31, p. 190]. XXI a. kultūros politikos sampratos tyrimuose ryškẻja pozicija kultūros politikos igyvendinimą teorizuoti remiantis keletu požiūrių: iš viešosios politikos teorinès prieigos; iš socialinès politikos konteksto; iš kultūros studijų antropologinès perspektyvos ir iš menų politikos kaip kultūros politikos dedamosios polio.

\section{Kultūros politikos įgyvendinimas kaip viešosios politikos ịgyvendinimo sritis}

Kultūros politikos ịgyvendinimo apibrèžimas bei esminių nuostatų ịvardijimas svarbus, nes tokiu būdu valstybės valdžia sprendžia: politinius klausimus, pasirinkdama kultūros valdymo metodus; ekonominius klausimus, pasirinkdama optimalius kultūros finansavimo metodus; organizacinius klausimus, nustatydama ir koordinuodama kultūros institucijų bei kultūros vertybių vartotojų tarpusavio san- 
tykius [38]. Kultūros politikos ịgyvendinimo kaip viešosios politikos srities analizė siejama su W. N. Dunn, W. Parsons, E. Lane, Ch. E. Lindblom tyrinètojų darbais. M. Weber, R. Denhardt ir H. Simon tyrimai suteikia igyvendinimo analizei teorinịmetodologini pamatą. W. Parsons teige, kad „viešosios politikos mokslų orientacija pripažista, jog viešoji politika ir problemos, kurios jai rūpi, nèra sudèliotos ị tvarkingas ir griežtai apibrěžtas akademinio tyrimo ribas" [24]. Viešosios politikos igyvendinimo požiūrio taikymas siekiant konceptualizuoti kultūros politikos ígyvendinimą, autorių nuomone, yra tikslingas, kadangi atskleidžia kultūros politikos igyvendinimo bendruosius politinius ir administravimo veiksnius. Juk kultūros politika nėra formuojama ir igyvendinama uždaroje terpeje, ją veikia daugybẻ aplinkos faktorių, kitų sričių politikos, ji pati yra ir mechanizmas, ir procesas, ir pokyčių (neretai net ir reformų) priežastis, ir pasekmè, ji kuria naujas ar palaiko nusistovèjusias sąlygas, sujungia ịvairaus profilio veikejjus (suinteresuotuosius), pasireiškia programų ir projektų vykdymu, visuomet yra orientuota į tikslus, o remiantis ir naujausia vadybine literatūra, siekiant efektyvumo ir etiškumo/teisingumo principu harmonijos privalo paisyti ir orientacijos ị rezultatus. Kultūros politikos igyvendinimo atveju, politikos rezultatai yra tiesiogiai ir netiesiogiai priklausomi nuo taisyklių sistemos, įstatymų ir kitu galiojančių normų, todèl kultūros politikai iškyla ir autonomijos nuo kitų sričių problema, taip pat ir demokratijos raiškos iggyvendinimo procese klausimai [7, p. 524].

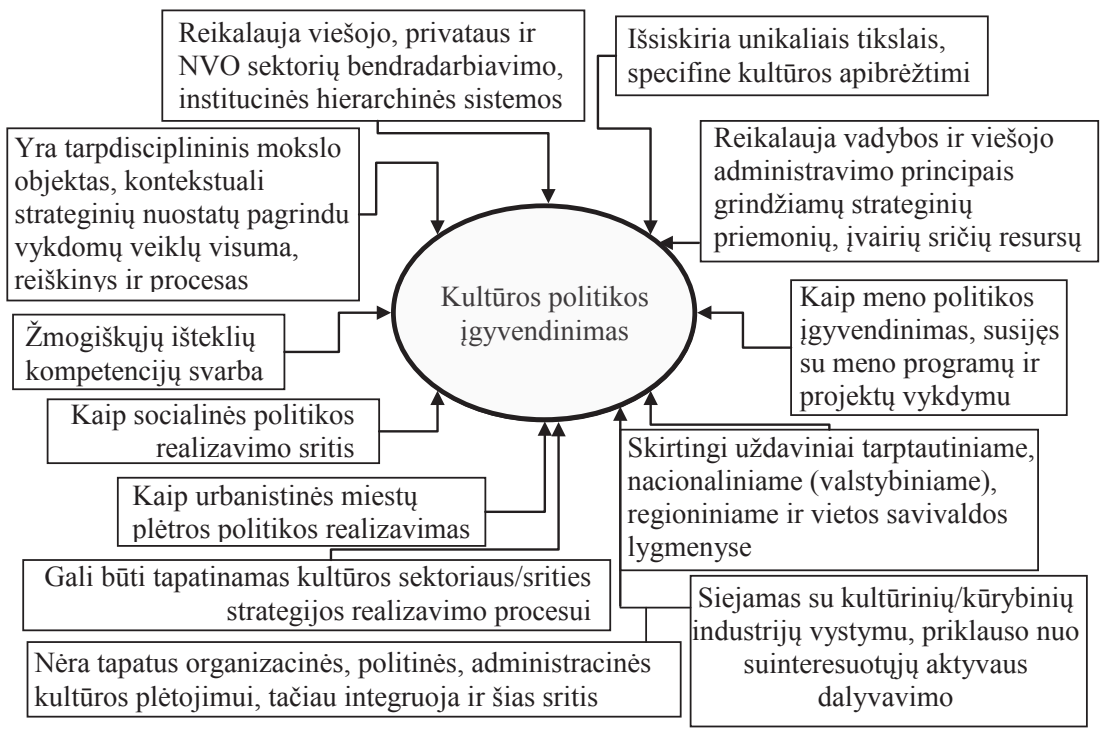

Šaltinis: sudaryta autorių, remiantis $[1 ; 4 ; 6 ; 11 ; 15 ; 16 ; 17 ; 18 ; 26]$.

1 pav. Kultūros politikos iggvendinimo sampratos turinys 
Apibūdinant kultūros politikos ịgyvendinimą susiduriama su konceptų įvairove ir tai apsunkina bendrą sampratos paieškos ar kūrimo procesą, kuria trukdžius vienodam supratimui, pateikiamuose požiūriuose pastebima, jog daugelyje kultūros politikos sampratų nepakankamas dėmesys yra skiriamas daugialypès sistemos supratimui, todèl neretai kultūros politika ir jos ịgyvendinimas tèra aiškinami kaip kitų sistemų elementas, o ne nepriklausoma sritis (pvz., socialinès srities dedamoji) (žiūrèti 1 pav.). Straipsnio autoriai kultūros politikos ịgyvendinimą ịvardija - kaip viešosios politikos srities - kultūros politikos - praktinio realizavimo, priskiriamo jau sukurtos strategijos vykdymui, sisteminį procesą, kurio metu veikia ịvairūs suinteresuotieji, valstybės valdžios institucijos vykdo ị tikslus ir rezultatus orientuotas veiklas. Kultūros politikos ịgyvendinimas negali būti nusakomas vien tik keletu teiginių, nes tai plati samprata, apimanti daug ịvairių dedamųjų. Ji visuomet išsiskiria unikaliais tikslais ir specifine kultūros apibrèžtimi, reikalauja vadybos ir viešojo administravimo principais grindžiamų strateginių priemonių, atspindi tarptautiniu, nacionaliniu (valstybiniu), regioniniu ir vietos savivaldos lygmeniu užsibrèžtus skirtingus uždavinius, aprėpia žmogiškųjų išteklių kompetencijų svarbos klausimą ir kt. svarbius elementus (žiūrèti 1 pav.). Kiekvienoje terpéje vyraujant skirtingoms tradicijoms kultūros politika gali būti ịgyvendinama ịvairiai.

Kultūros politikos įgyvendinimas gali būti tapatinamas su kultūros sektoriaus/ srities strategijos realizavimo procesu. Jei kultūros sektoriuje vykstantys procesai yra matomi kaip norimos vystyti sritys, tuomet strateginio planavimo metodologija dažnai yra būdas tendencingai nukreipti visumą veiklų bendro tikslo pasiekimo linkme, o tai skatina plètoti ir šiame sektoriuje efektyviai derinti tiek kultūros ekonomikos (kultūros ir kūrybinių industrijų), tiek ir kūrybiškumo principų pagrindu veikiančius darinius, bendradarbiavimo kultūrą pačiame sektoriuje, orientaciją i pokyčius. Neretai kultūros politikos ịgyvendinimo kontekste susipina rinkos, kūrybiškumo ir valstybès socialinès plètros pozicijos, tam tikra hipotetinè demarkacinè linija tarp šiu polių išnyksta [23, p. 7]. O tai taip pat suvokiama kaip kliūtis ar bent jau iššūkis konceptualizuojant kultūros politikos ịgyvendinimą.

\section{Kultūros politikos įgyvendinimo valstybiniu lygmeniu modeliai}

Kultūros politikos igyvendinimą traktuojant kaip kompleksą vadybinių/ administracinių procesų, inicijuojamų valstybiniu lygmeniu, ir pati igyvendinimą suvokiant visų pirma kaip valdžios institucijų vykdomas priemones politikos tikslams pasiekti, strateginis planavimas tampa metodologiniu ịrankiu valstybès (kaip organizacijos) iggaliotų institucijų kontekste modeliuojant kultūros politikos igyvendinimą (kuriant ir konceptualizuojant iggyvendinimo modelius), tikima, kad galima pasiekti norimus rezultatus greičiau, racionaliau ir tikslingiau. Strateginis planavimas didina kultūros organizacijų atsakomybę ir gerina jų veiklą sprendžiant esmines vidaus ir išorès problemas, leidžia lanksčiau ir efektyviau keisti veiklos kursą atsižvelgint ị aplinkybes, t. y. strateginį mąstymą tvirtai susieja su strateginiu 
veikimu [27]. Taigi strateginio planavimo ir kultūros politikos igyvendinimo susiejimas tampa neišvengiamas. Visų strateginių ciklų (kurių kiekvienas, remiantis M. Bryson, išreiškia tam tikrą specifinę strateginę veiklą) valdymas kultūros politikos igyvendinimo modelių kontekste yra vertingas, nes valstybėms atveria naujų galimybių kreipiant organizacijas ị kultūros programose užkoduotus rezultatus $[8 ; 9$, p. 6]. Mokslinèje literatūroje skiriami trys planavimo modeliai, savaip atspindintys skirtingas kultūros politikos iggyvendinimo kryptis (žiūrèti 1 lentelę).

1 lentele. Trys strateginiai planavimo modeliai, orientuoti ị skirtingas kultūros politikos igyvendinimo kryptis

\begin{tabular}{|c|c|c|}
\hline $\begin{array}{l}\text { Kultūros planavimas } \\
\text { (kultūros strategijos } \\
\text { igyvendinimo modelis, } \\
\text { kai ilgalaikejje kultūros } \\
\text { sektoriaus vystymo } \\
\text { perspektyvoje valstybiniu } \\
\text { ar tarptautiniu lygmeniu } \\
\text { vadovaujamasi } \\
\text { planavimo, orientuoto } \\
\text { ị kultūros politikos } \\
\text { formavimo tradicijas } \\
\text { pavyzdžiu, ịvertinant } \\
\text { kultūrinị bendruomenès, } \\
\text { tautos, regiono ar } \\
\text { valstybės/ių potencialą ir } \\
\text { savitumą) }\end{array}$ & $\begin{array}{l}\text { Menų politika } \\
\text { (kultūros strategijos } \\
\text { igyvendinimo modelis, } \\
\text { kai dažniausiai } \\
\text { valstybiniu lygmeniu } \\
\text { ilgalaikejje kultūros } \\
\text { sektoriaus vystymo } \\
\text { perspektyvoje labiausiai } \\
\text { akcentuojamos skirtingos } \\
\text { menų sritys ir šakos, } \\
\text { siekiama užtikrinti } \\
\text { geriausias sąlygas meno } \\
\text { kūrybos, saugojimo ir } \\
\text { sklaidos procesams, } \\
\text { taip pat akcentuojami } \\
\text { meno vartotojų ugdymo } \\
\text { aspektai) }\end{array}$ & $\begin{array}{l}\text { Kūrybiniai miestai } \\
\text { (kultūros strategijos } \\
\text { igyvendinimo modelis, savo } \\
\text { turiniu labiau orientuotas } \\
\text { ị vietinị (lokalų) lygmenį, } \\
\text { kai ilgalaikèje kultūros } \\
\text { sektoriaus vystymo } \\
\text { perspektyvoje fokusuojamasi } \\
\text { ị miestų kultūrinio/kūrybinio } \\
\text { išskirtinumo puoselèjimą, } \\
\text { vertinant juos kultūros } \\
\text { ekonominio poveikio aspektu, } \\
\text { ižzelgiant jų kaip kūrybos } \\
\text { procesų katalizatorių reikšmę } \\
\text { tiek vietinės, tiek ir tarptautinès } \\
\text { konkurencijos kontekste) }\end{array}$ \\
\hline $\begin{array}{l}\text { Plačioji antropologinė } \\
\text { kultūros definicija }\end{array}$ & $\begin{array}{l}\text { Siauroji humanistinè } \\
\text { kultūros definicija }\end{array}$ & $\begin{array}{l}\text { Kultūros kaip patirties } \\
\text { definicija }\end{array}$ \\
\hline $\begin{array}{l}\text { Kūrybiškumas - vietinis } \\
\text { išteklis }\end{array}$ & $\begin{array}{l}\text { Kūrybiškumas - estetinių } \\
\text { eksperimentų su jiems } \\
\text { būdinga dvasine, } \\
\text { moraline kultūrine verte } \\
\text { išraiška }\end{array}$ & $\begin{array}{l}\text { Kūrybiškumas - ekonominis } \\
\text { kapitalas }\end{array}$ \\
\hline $\begin{array}{l}\text { Strateginis kultūros } \\
\text { priemonių naudojimas } \\
\text { vystant bendruomenes }\end{array}$ & $\begin{array}{l}\text { Strateginis menų sričių, } \\
\text { šakų vystymas }\end{array}$ & $\begin{array}{l}\text { Kultūros pagrindu kuriama } \\
\text { ekonominė strategija, } \\
\text { grindžiama 3T logika } \\
\text { (tolerancija, talentas, } \\
\text { technologija) }\end{array}$ \\
\hline $\begin{array}{l}\text { Miestai kaip vietinès } \\
\text { erdvės, georgrafinis } \\
\text { požiūris }\end{array}$ & $\begin{array}{l}\text { Miestai kaip menų } \\
\text { erdvės, } \\
\text { kultūriniai sektoriai }\end{array}$ & $\begin{array}{l}\text { Miestai kaip tarptautiniai } \\
\text { konkurentai }\end{array}$ \\
\hline
\end{tabular}

Šaltinis: adaptuota pagal [13, p. 194] 
Kultūros planavimo, menų politikos ir kūrybinių miestų modeliai savo savastimi skiriasi tiek strateginemis orientacijomis, tiek pačios kultūros traktavimu, miesto koncepto apibrèžtimi, kūrybiškumo dimensijos išskyrimu. Kūrybinių miestų modelis ekonomiškai yra potencialiai sèkmingas, nukreiptas ị kultūros pagrindu kuriamą tolerancijos, talento ir technologijos - trijų T koncepcijos praktinị taikymą ivairiose su strategija susijusiose veiklose, yra orientuotas ị tarptautinio konkurencinio pranašumo formavimą ar puoselejjimą. Tuo tarpu kultūros planavimo ar menų politikos strateginiai modeliai akcentuoja antropologinius ir bendrasociologinius kultūros srities faktorius. Strateginis menų sričių, šakų vystymas yra svarbiausias menų politikoje, o kultūros planavimo strateginis orientyras - kultūros priemonių naudojimas vystant bendruomenes. Svarbu papildyti, jog šiuolaikiniai tyrimai kultūros politikos igyvendinimo modelių kontekste akcentuoja ir perejjimą nuo strateginio planavimo link inovacijų planavimo [3, p. 74], tai taip pat kuria naujus iššūkius kultūros politikos igyvendinimo etapuose. Strateginiai planavimo modeliai, priklausomai nuo dominuojančių pozicijų, skatina ir plètoja tam tikrą kultūros politikos ịgyvendinimo institucinị modelị.

Kiekvienos valstybės nacionalinès kultūros politikos kryptys priklauso nuo tos šalies bendrosios politinès, ekonominès ir kultūrinès būklès. Kiekvienas kultūros politikos modelis atspindi konkrečios valstybès kultūros bendrąsias vystymosi ir vystymo strategijas ir jų mechanizmus [39]. Mokslinèje literatūroje nurodomi šie kultūros politikos igyvendinimo modeliai: valstybinis kultūros politikos modelis (dar vadinamas ir valstybiniu-biurokratiniu), kuriam būdinga valstybinė kultūros reiškinių, jų pagrindu kuriamų produktų platinimo nuosavybė, ir liberalusis kultūros politikos modelis, kurio svarbiausiu požymiu yra laikoma privati kultūros reiškinių ir vadinamųjų kultūros produktų platinimo nuosavybẻ. Valstybinis kultūros politikos modelis dar vadinamas švietejjišku, kadangi esminiai sprendimai yra priimami „biurokrato“ - valstybės valdžios institucijoje dirbančio specialisto, ir taikant tam tikras priemones yra nukreipti visuomenès kultūrinio skonio formavimo linkme $[9 ; 10 ; 38]$. Taip pat skiriami trys modeliai, pagal prigimtị akcentuojantys skirtingas valdymo savybes. Rankos atstumo kultūros politikos modelis - valstybės nenusišalinimas nuo kultūros plètros taip, kaip liberaliojo modelio taikymo procesuose, bet laikymasis tam tikru „rankos atstumu“ [10]. Taikant ši politikos igyvendinimo modeli, valdymo funkcijos atitinkamam laikotarpiui pavedamos specialioms institucijoms, papildomą reikšmę igauna ekspertų grupių, neretai meno tarybų veikla. Tautos emancipacijos kultūros politikos modelis turi tiek valstybinio, tiek liberaliojo modelio požymių. Svarbu akcentuoti, jog valstybinis prestižo kultūros politikos modelis ryškiausiai taikomas Prancūzijoje, kadangi ši valstybė èmèsi tautos kultūrinio identiteto išsaugojimo iniciatyvos, vertindama šią misiją kaip šalies prestižo formavimo būdą pasaulyje. Švedijoje pastebima „rankos atstumo“ kultūros politikos modelio atmaina - dvigubo „rankos atstumo“ kultūros politikos modelis, orientuojantis valstybę didesnio kultūros decentralizavimo link. Europoje dažniausiai kalbama apie Šiaurès šalių kultūros politikos modelį, britiš- 
ką ir prancūzišką modelius, pastebima, kad prestižo - švietèjiško kultūros politikos modelio ịgyvendinimas yra gana brangus procesas [19; 39]. Kultūros politikos modelių igyvendinimas priklauso ir nuo valstybeje vyraujančio socialinio modelio savybių. Juk socialinio potencialo suaktyvinimas ir valstybės socialinio atsakingumo didinimas yra svarūs argumentai, nustatant institucinius pokyčius, pasirenkant lanksčias rinkos ir valstybinio reguliavimo sąveikos priemones [28]. Skiriami šie socialiniai valstybès modeliai: liberali gerovès (pvz., JAV, Anglija, Kanada); socialinès demokratinės gerovės (pvz., Švedija) ir korporatyvinis gerovės valstybės modelis (pvz., Vokietija). İvairius kultūros politikos ịgyvendinimo modelius veikia skirtingų kultūros/menų sferos bei politikos, administravimo ir ekonomikos sferos interesų sankirtos/derinimo laukas (žiūrèti 2 pav.).

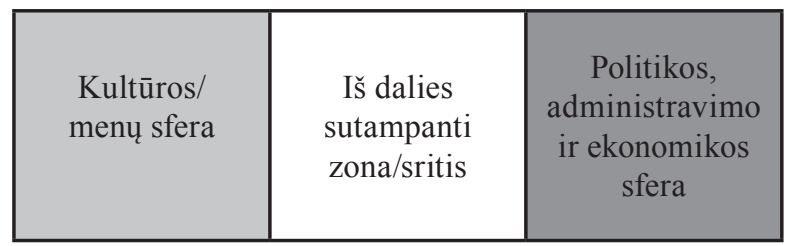

Šaltinis: [37, p. 534].

2 pav. Iš dalies sutampanti zona/sritis kaip kultūros/menų sferos bei politikos, administravimo ir ekonomikos sferos skirtingų interesų derinimo laukas

Anot G. Vestheim, kuris ịkvėptas P. Bourdieu socialinio ir kultūrinio kapitalizmo teorijos parengè koncepcini modelị, aiškinantị, jog „egzistuoja iš dalies sutampanti zona/sritis tarp kultūros/menų sferos/sektoriaus ir politikos, administravimo bei ekonomikos sferos/sektoriaus, kur susijungia arba konfrontuoja minètu sektorių suinteresuotųjų pozicijos" [37]. Tai tam tikras interesų derinimo, o kartu ir konkurencijos laukas, kurio reikšmė - skirtingų požiūrių vienovès ar bent jau bendro konsensuso radimo siekis. Konceptualizuojant kultūros politikos igyvendinimo modelius, svarbu akcentuoti ir tokio lauko egzistavimą, įvardijant jị kaip sferą, kai tie patys suinteresuotieji neretai atstovauja netgi dviem sektoriams/sritims: kultūros/menu ir politikos/administravimo bei ekonomikos. Konsensuso radimas - tai sudetingas politinis ir administracinis klausimas, nes ypatingai valstybiniu lygmeniu daug problemų pastebima būtent kultūros sektoriuje - patiems šios dimensijos suinteresuotiesiems dažnai nerandant bendro vardiklio kultūros ir jos sričių apibrèžties klausimais. Tai dar viena teorinio konceptualizavimo ir kultūros politikos igyvendinimo modelių praktikos problema. Kitas svarbus G. Vestheim modelio aspektas - kultūrinio kapitalo, kurị gamina visos iš dalies sutampančioje zonoje susikertančios jègos, paskirstymas socialinių ryšių sistemos įtakos zonose (įskaitant ir finansini šio kapitalo pamatą). Todèl apibūdinamas modelis tampa aktualus kultūros politikos iggyvendinimo sferose, susijusiose su valstybės parama kultūros srities 
objektams ir subjektams. Visų kultūros politikos ịgyvendinimo modelių kontekste ryškèja tam tikra pirminè proceso formavimo fazè, kurios rezultatas - sektoriaus/ srities strategijos sukūrimas ir ịgyvendinimo proceso etapai. Minètas kultūros politikos ịgyvendinimo dedamąsias straipsnio autoriai mato ir viešosios politikos ịgyvendinimo proceso bendrųjų kintamųjų sąveikoje, atvaizduotoje trečiame paveiksle (žiūrèti 3 pav.).

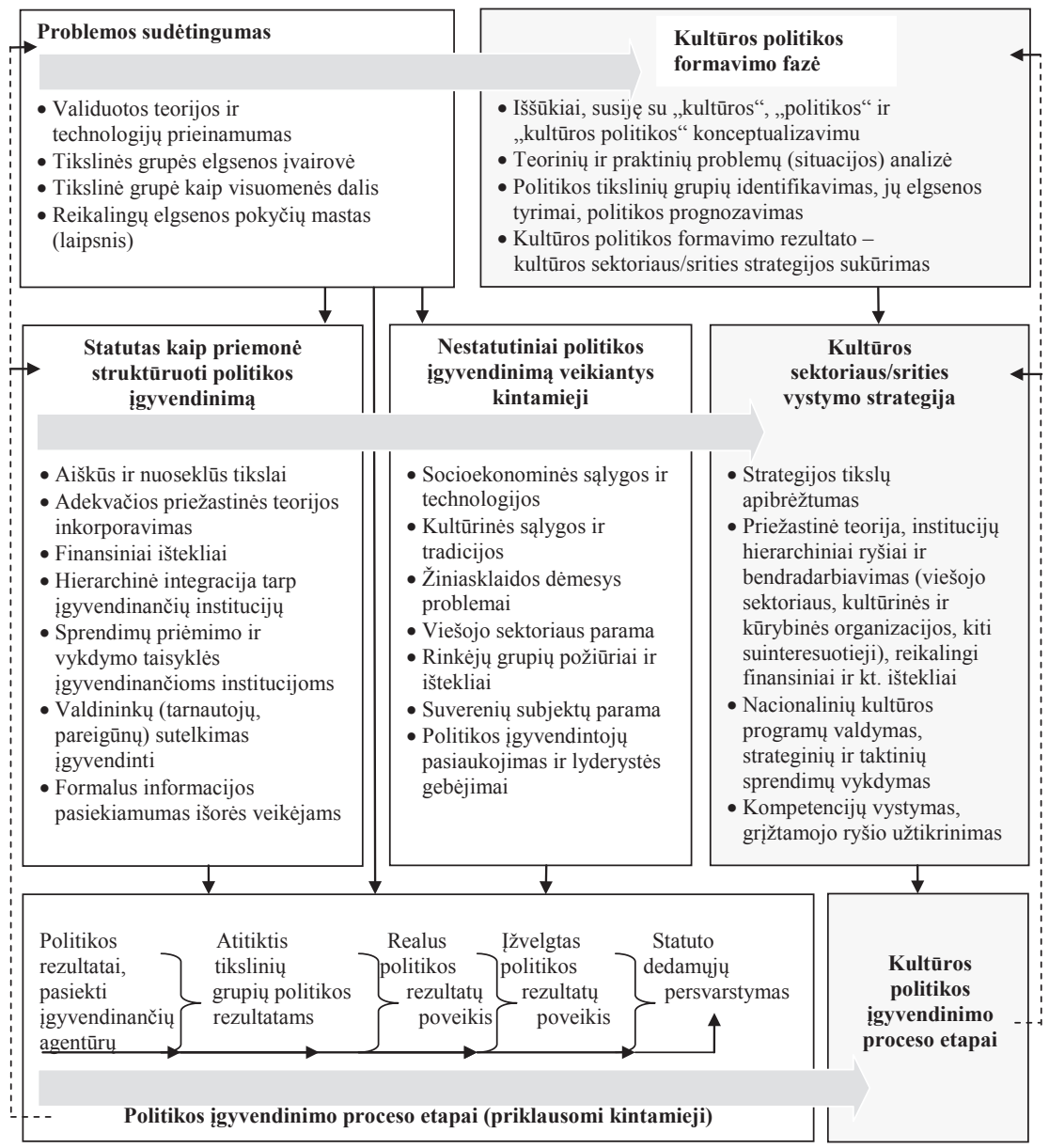

Šaltinis: sudaryta autorių, pagal [29; 30, p. 154].

3 pav. Kultūros politikos formavimo fazès, sektoriaus/srities strategijos ir igyvendinimo proceso etapų susiejimas su politikos įgyvendinimo proceso bendrųjų kintamųjų sąveika 
Viešosios politikos ir kultūros politikos igyvendinimo atitikties modelis paremtas klasikinėmis P. A. Sabatier ir D. Mazmanian išvadomis integruoja ir bendrają strategijos igyvendinimo proceso logiką [29; 30, p. 154]. 3 pav. adekvačios priežastinès teorijos inkorporavimas reiškia, jog statutas turi būti pagrịstas geriausiai tinkančia teorija, kuri nurodo priežasties ir pasekmės ryšius (pvz., sisteminiu požiūriu, procesiniu požiūriu ir kt.). Kultūros politikos igyvendinimo etapai savo esme atitinka bendrosios politikos ịgyvendinimo etapus, tačiau kiekviename jų susiduriama su srities iššūkių formuojamais elementais. Statutas - tai įstatymų rinkinys, nustatantis institucijos/organizacijos struktūrą, jos veiklos principus ir reiškiantis įstatymus igyvendinančių aktų pavadinimą [35, p. 927]. Tačiau aprašomoje sąveikoje šis konceptas vartojamas perkeltine prasme, turint omenyje svarbiausią politikos pozicijas apibrèžiantị dokumentą (pvz., strategiją, nuostatas, gaires ir kt.). Inkorporavimas - normatyvinès medžiagos sisteminimo forma [35, p. 411], sąveikoje ịtraukta siekiant pabrèžti pasirenkamos priežastinès teorijos aiškios taikymo logikos svarbą. Priežastinè teorija siejama su terminu „kauzalinis“ (lot. causalis priežastinis) - tai tam tikri priklausomybès santykiai, kuriems svarbus išaiškintų priežastinių ryšių patikrinimas duomenimis [35, p. 206; 473]. Kultūros politikos igyvendinimo, kurị straipsnio autoriai išskaido ị kultūros politikos formavimo fazę, sektoriaus/srities strategiją ir igyvendinimo proceso etapus, susiejimas su politikos igyvendinimo proceso bendrųjų kintamųjų sąveika atskleidžia, jog procesinis kultūros politikos igyvendinimo vaizdavimas glaudžiai siejasi su bendrąja viešosios politikos igyvendinimo logika, abu procesus veikia tie patys nestatutiniai politikos igyvendinimo kintamieji. Pastebimas kultūros politikos formavimo fazès rezultatų priklausymas nuo užsibrezžtos problemos, išskiriama ir bendroji igyvendinimo proceso logika, kai svarbiausia ne tik pasiekti laukiamą poveikį, bet ir užtikrinti grịžtamąji ryši - sukurtos strategijos koregavimą, vadybinių procesų tobulinimą. Kultūros politikos igyvendinimo proceso etapų aiškinimas galètų būti tolesnių tyrimų šioje srityje remiantis pateiktuoju modeliu tikslas. Tačiau apibūdinamoje sąveikoje detaliau išskaidomas juos veikiantis bendrasis viešosios politikos ịgyvendinimo proceso etapų (priklausomų kintamųjų) laukas. Paprastos rodyklés modelyje nurodo hierarchinius ryšius, o punktyrinėmis rodyklèmis atvaizduotas siektinas grịžtamasis ryšys.

Apibendrinant verta pasakyti, kad kultūros politikos igyvendinimas yra siejamas ne tik su socioekonominiais, politiniais ir administraciniais globaliais antecedentais, bet ir su kultūros kaip reiškinio (fenomeno), kultūros politikos turinio ir logikos, vadybinių procesų, reikalingų kultūros politikos tikslams pasiekti, identifikavimu konkrečioje valstybeje. Tačiau nepaisant probleminių teorinių aspektų, kultūros politikos igyvendinimo modeliai globalizuotame pasaulyje tampa vis svarbesnèmis ị pažangą ir pokyčių valdymą orientuotų valstybių konceptualiomis priemonėmis ir ịvertinus sąlygas, aplinką bei strateginius tikslus, renkantis atitinkantị modeli yra darniau ir racionaliau kuriamas kultūros potencialo vystymo valstybėse procesas. 


\section{Išvados}

Dèl istoriškai susiklosčiusio kultūros politikos ịgyvendinimo daugiadimensiškumo ir tarpdiscipliniškumo kultūros politikos ịgyvendinimo kaip viešosios politikos igyvendinimo srities ar jos dedamosios konceptualizavimas yra neišvengiamai sietinas su ịvairiomis teorinėmis orientacijomis. Konceptualizuojant kultūros politikos ịgyvendinimą yra svarbi ne tik kultūros sampratų ịvairovė, terminų interpretavimo keliami iššūkiai, bet ir pakankama bei adekvati igyvendinimo proceso teoriné apibrezžtis. Šiuolaikiniuose kultūros politikos igyvendinimo tyrimuose vadybos ir viešojo valdymo mokslų kontekste ryškẻja tikslingai suformuotos strategijos vykdymo svarbos išskyrimas ir kultūros politikos ịgyvendinimo proceso susiejimas su viešosios politikos igyvendinimo metu taikoma strateginio planavimo priemonių visuma.

Kultūros politikos igyvendinimo modeliai skiriasi kultūros sampratos traktuotemis ir strateginėmis kryptimis. Siekiant perprasti kultūros politikos įgyvendinimą, įmanoma ji susieti su viešosios politikos igyvendinimo proceso bendraisiais kintamaisiais, kurių kontekste ryškejja kultūros politikos formavimo fazės rezultatų priklausymas nuo užsibrèžtos problemos, sektoriaus/srities strategiją veikiančių nepriklausomų kintamųjų ịtaka ir bendroji igyvendinimo proceso logika, kai yra vienodai svarbu ir pasiekti laukiamą poveikị, ir užtikrinti grịžtamąjị ryšị. Kultūros politikos ịgyvendinimo modeliai yra neišvengiamai siejami su socialinio pasaulio ryšių ir sąveikų sistemomis, taip pat atsižvelgiant ị teorinị požiūrị gali būti grupuojami pagal dominuojantị kultūros kaip visumos ar jos vystymo srities požiūrị.

\section{Literatūra}

1. Ahponen, P.; Kangas, A. Conclusion. Construction of Cultural Policy. In: P. Ahponen and A. Kangas (eds.). Jyväskylä: SoPhi 94, Minerva, 2004, 245-248.

2. Alperyte, I. Business Culture in Lithuania: Trying to Fill Institutional Voids. The 6th International Scientific Conference "Business and Management 2010". Vilnius, Lithuania 13-14 May 2010. Selected papers. Vilnius: Gediminas Technical University, 2010, 303-310.

3. Bason, Ch. Leading Public Sector Innovation. Co-creating For a Better Society. Chicago: Policy Press, 2014.

4. Belfiore, E.; Bennett, O. The Social Impact of the Arts: An Intellectual History. Basingstoke: Palgrave MacMillan, 2008.

5. Bennett, T. Culture and Governmentality. Foucault, Cultural Studies, and Governmentality. In: J. Z. Bratich, J. Packer, C. McCarthy (eds.). Albany: State University of New York Press, 2003, 47-63.

6. Bianchini, F. Remaking European Cities: The Role of Cultural Policies. Cultural Policy and Urban Regeneration: The West European Experience. In: F. Bianchini and M. Parkinson (eds.), Manchester: Manchester University Press, 1993, 199-213. 
7. Blomgren, R. Autonomy or Democratic Cultural Policy: that is the Question. International Journal of Cultural Policy, Vol. 18, No. 5, 2012, 519-529.

8. Bryson, J. M. Strategic Planning for Public and Nonprofit Organizations. San Francisco: Jossey-Bass Publishers, 1995.

9. Bučinskas, A.; Raipa, A.; Pauliukevičiūtè, A. Strateginis planavimas kultūros politikos igyvendinimo kontekste. Tiltai/Bridges, 2009, Vol. 3, 1-15.

10. Bučinskas, A.; Raipa, A.; Pauliukevičiūtè, A. Modern Aspects of Implementation of Cultural Policy. Tiltai/Bridges, 2010, Vol. 4, 1-14.

11. Duelund, P. (ed.). Cultural Policy: An Overview. The Nordic Cultural Model. Nordic Cultural Policy in Transition. Copenhagen: Nordic Cultural Institute, 2003, 13-31.

12. Dunn, W. N. Public Policy Analysis. Vilnius: Homo Liber, 2006.

13. Hansen, D. S. Whose City? Planning for Creativity and Cultural Diversity. What about Cultural Policy? Interdisciplinary Perspectives on Culture and Politics. In: M. Pyykkönen, N. Simanainen, S. Sokka (eds.). Helsinki, Jyväskylä: Minerva Kustannus Oy., 2009, 193-208.

14. Hofstede, G. Culture's Consequences: International Differences in Work-Related Values. London and Beverly Hills: Sage Publications, 1980, 328.

15. Gray, C. Analysing Cultural Policy: Incorrigibly Plural or Ontologically Incompatible? Paper presented at The 5th International Conference on Cultural Policy Research (ICCPR), Istanbul: Yeditepe University, August 20-24, 2008. http://iccpr2008. yeditepe.edu.tr/papers.html [2014-04-10].

16. Gray, C. Managing Cultural Policy: Pitfalls and Prospects. Public Administration. Oxford: Blackwell Publishing Ltd. 2009, Vol. 87, No. 3, 574-585.

17. Johannisson, J. A Sense of Place? Tracing a Spatial Approach to Cultural Policy. What about Cultural Policy? Interdisciplinary Perspectives on Culture and Politics. In: M. Pyykkönen, N. Simanainen, S. Sokka (eds.). Helsinki, Jyväskylä: Minerva Kustannus Oy, 2009, 173-193.

18. Johannisson, J. The Geography of Cultural Policy: Regional Cultural Policy in Sweden. Paper presented at The 5th International Conference on Cultural Policy Research (ICCPR), Istanbul: Yeditepe University, August 20-24, 2008.

19. Kačkutè, R. Kultūros politikos modeliai Europoje. Pranešimas, skaitytas 2008 m. spalio 8 d. Kultūros ir meno taryboje. Literatūra ir menas, 2008, nr. 3209, http://www. culture.1t/lmenas/?st_id=13623 [2014-04-10].

20. Laitin, D. D. Hegemony and Culture: Politics and Religious Change Among the Yoruba. Chicago: University of Chicago Press, 1986.

21. Liutkus, V. Compendium Cultural Trends in Europe. Country Profile Lithuania. Council of Europe/ERICarts, 12th edition, 2011.

22. Mitchell, R. Nordic and European Cultural Policies. The Nordic Cultural Model. In: P. Duelund (ed.). Copenhagen: Nordic Cultural Institute, 2003, 437-478.

23. O'Brien, D. Cultural Policy: Management, Value and Modernity in the Creative Industries. New York: Routledge, 2014.

24. Parsons, W. Viešoji politika. Politikos analizès teorijos ir praktikos įvadas. Vilnius: Eugrimas, 2001. 
25. Pirnes, E. Meaningful Culture and Cultural Policy. A Broad Concept of Culture as a Basis for Cultural Policy. (Merkityksellinen kulttuuri ja kulttuuripolitiikka. Laaja kulttuurin käsite kulttuuripolitiikan perusteluna). In: J. Kotkavirta; I. Ylönen, M. L. Tynkkynen (eds.). Jyväskylä: University of Jyväskylä. 2008. no. 327, https://jyx.jyu.fi/ dspace/bitstream/handle/123456789/18544/9789513930851.pdf?sequence=1 [2014-0410].

26. Pyykkönen, M.; Simanainen, N.; Sokka, S. Introduction - O Culture, Where Art Thou? What about Cultural Policy? Interdisciplinary Perspectives on Culture and Politics. In: M. Pyykkönen, N. Simanainen, S. Sokka (eds.). Helsinki, Jyväskylä: Minerva Kustannus Oy, 2009, 11-31.

27. Raipa, A. Strateginis planavimas viešajame administravime. Kn.: Viešasis administravimas. Sud. A. Raipa. Kaunas: Technologija, 2007, 274-293.

28. Rakauskienė, O. G. Valstybès ekonominè politika. Vilnius: Mykolo Romerio universitetas, 2006.

29. Sabatier, P. A.; Mazmanian, D. The Implementation of Public Policy. A Framework for Analysis. Policy Studies Journal, 1980, No. 8, 538-560.

30. Sabatier, P. A.; Mazmanian, D. A Conceptual Framework of the Implementation Process. Public Policy. The Essential Readings. In: S. Z. Theodoulou, M. A. Cahn (eds.). New Jersey: Prentice Hall, Englewood Cliffs, 1995, 153-173.

31. Schedler, K.; Proeller, I. Public Management as a Cultural Phenomenon Revitalizing Societal Culture in International Public Management Research. International Public Management Review, 2007, Vol. 8, No. 1, 186-194, http://www.ipmr.net [2014-04-10].

32. Thompson, K. Cultural Studies, Critical Theory and Cultural Governance. International Sociology, 2001, Vol. 16, No. 4, 593-605.

33. Williams, R. Keywords: A Vocabulary of Culture and Society. Glasgow, London: Fontana Paperbacks, 1983.

34. Van Maanen, J. E.; Schein, E. H. Towards a Theory of Organizational Socialization. Research in Organizational Behavior. Greenwich: JAI, 1979, No. 1, 209-264.

35. Vaitkevičiūtè, V. Tarptautinių žodžių žodynas. Vilnius: Žodynas, 2001.

36. Varbanova, L. Strategic Management in the Arts. New York, London: Taylor and Francis Group, 2013.

37. Vestheim, G. Cultural Policy-Making: Negotiations In an Overlapping Zone Between Culture, Politics and Money. International Journal of Cultural Policy, 2012, Vol. 18, No. 5, 530-544.

38. Vilkončius, L. Kultūros politika lemia valstybès valdžios apsisprendimas. Kn.: Žalpys, E. (red.). Meno aritmetika - kultūros vadyba Lietuvoje. Vilnius: Tyto alba, 2004, 20-41.

39. Vilkončius, L. Lietuvos kultūros politika ir kultūros įstaigų veiklos administravimas. Kn.: Bartkevičiūtè, I.; Bèkšta, A.; Makselis, R.; Simonavičienė, Ž.; Vilkončius, L. (red.). Šiuolaikinis kultūros įstaigų administravimas ir valdymas. Vilnius: Lietuvos kultūros darbuotojų tobulinimosi centras, 2007, 13-15. 
Audronė Pauliukevičiūtė, Alvydas Raipa

\title{
Cultural Policy Implementation: Theoretical Conceptualization and Models
}

\begin{abstract}
Rapidly changing global and technological world, continuous progressive change and cultural transformations determine changes in country's management systems, in separate spheres of public policy and management. Cultural policy implementation is influenced by political/ideological, economic/organizational, cultural/technological challenges, and despite many research projects that are analyzing questions of cultural policy, there is still a lack of a broader approach to cultural policy conceptualization, process related problems. Therefore, the goal of this article is to reveal theoretical conceptualization of cultural policy implementation and its models. The object of the work is cultural policy implementation concepts and theoretical models. Two objectives have been formulated, seeking to achieve the main goal: conceptualize the cultural policy, reviewing concept interpretations, also describing cultural policy implementation as a sphere of public policy implementation; describe state level cultural policy implementation theoretical models. The authors of this article provide a wide range spectrum of cultural policy implementation concepts, describing basic models, revealing and visualizing cultural policy implementation process in the context of general variables of public policy implementation process (regardless of any of the model chosen).
\end{abstract}

Audrone Pauliukevičiūtè - Kauno technologijos universiteto Ekonomikos ir verslo fakulteto Strateginio valdymo katedros doktorantè, viešojo administravimo magistrè.

E. paštas: audrone.pauliukeviciute@ktu.lt, audrone_pauliukeviciute@yahoo.com

Alvydas Raipa - Mykolo Romerio universiteto Politikos ir vadybos fakulteto Viešojo administravimo instituto profesorius, socialinių mokslų daktaras.

E. paštas: alvydasraipa@mruni.eu

Audrone Pauliukevičiūtè, Master of Public Administration, Kaunas University of Technology, Faculty of Economics and Management, Department of Strategic Management, Doctoral student.

E-mail: audrone.pauliukeviciute@ktu.lt, audrone_pauliukeviciute@yahoo.com

Alvydas Raipa, Habilitated Doctor of Social Sciences, Mykolas Romeris University, Faculty of Social Sciences, Institute of Public Administration, Professor.

E-mail: alvydasraipa@mruni.eu

Straipsnis įteiktas redakcijai 2014 m. gegužès 2 d.; recenzuotas; parengtas spaudai 2014 m. gegužès $25 \mathrm{~d}$. 